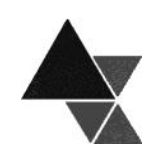

\title{
Evaluation of security and hygiene of workers in open market in Palmas - Tocantins
}

\author{
Wantiê Teles Adorno ${ }^{1}$, Glêndara Aparecida de Souza Martins ${ }^{2}$, Silvana Marques Filgueiras \\ Teixeira ${ }^{3}$, Kássio Renê Dias Wanderley ${ }^{4}$, Denise Gomes Alves ${ }^{5}$
}

As feiras apresentam graves problemas como falta de higiene, má estrutura das barracas, falta de segurança e desorganização. Tais problemas colocam em risco a sobrevivência da feira, uma vez que contrariam a legislação sanitária. O presente trabalho tem como objetivo mapear os riscos ambientais existentes nas feiras livres mais frequentadas na cidade de Palmas - TO, bem como estabelecer as medidas de controle necessárias à manutenção da saúde e segurança dos trabalhadores e consumidores. O trabalho foi realizado em duas feiras, sendo uma na região sul e região norte. Foram realizadas avaliações qualitativas in loco, utilizando a avaliação em segurança do trabalho para feiras livres. Para estudo quantitativo procedeu-se a medição do nível de ruído, temperatura e iluminância. Os problemas enfrentados pelos feirantes são as temperaturas elevadas, instalações elétricas de má qualidade, aliados ao cansaço físico, psicológico, estresse por efeito do nível elevado de ruído, dor nas pernas e costas, o que coloca em risco à segurança física e psicológica do trabalhador. Constatando-se a necessidade de investimentos do poder público, direcionados a melhorias na estrutura física das feiras. Como mudança de layout, modernização das instalações, agindo na redução de acidentes e incidentes nestes ambientes ocupacionais, e na prevenção de toxinfecções alimentares.

Palavras-chave: feiras livres, layout, mapa de risco, riscos ambientais.

\section{Avaliação de segurança e higiene dos trabalhadores das feiras livres em Palmas - Tocantins}

Fairs show serious problems in many ways such as poor hygiene, poor structure of tents, disorganization, and lack of security, these problems endanger the survival of the fair, since health legislation is not fulfilled. The goal of this study was to map the environmental risks in the busiest free markets in the city of Palmas - TO, even as determine the control measures necessary to maintain the health and safety of workers and consumers. The work was performed in two fairs, one located in the southern region of Palmas, and the other located in the northwar. Qualitative assessments were performed in situ using the assessment in occupational safety to fairs. For quantitative study the level of the noise, temperature and luminance were measured. The major problems faced by stallholders were high temperatures, poor quality electrical installations, together physical fatigue, psychological stress due to action of high levels of noise, pain in legs and back, that endangers physical and psychological security of workers. Besides, was noticed the need of investments from the government, improving the

\footnotetext{
${ }^{1}$ Engenheiro de Alimentos - Laboratório de Microbiologia e Bioprocessos. Correspondência: Av. NS 15, ALCNO 14, Bloco II, Sala 07 - Caixa Postal: 114. CEP: 77001-090. Telefone: +55(63) 3232-8085. E-mail: wantie_adorno@hotmail.com.

${ }^{2}$ Doutora em Biotecnologia. Professora de Engenharia de Alimentos da Universidade Federal do Tocantins.

${ }^{3}$ Inspetora Sanitária da Vigilância Municipal de Palmas - Tocantins.

${ }^{4}$ Aluno do Curso de Engenharia de Alimentos da Universidade Federal do Tocantins.

${ }^{5}$ Doutora em Engenharia de Alimentos. Professora de Engenharia de Alimentos da Universidade Federal do Tocantins.
} 
physical structure of the fairs. Furthermore, layout changes, upgrading facilities and the application of new technologies will be able to minimize, and may bee liminate hazards and critical control points at the fairs reducing not only accidents as well as to preventing food poisoning.

Key-words: fairs, layout, risk map, environmental risks.

\section{INTRODUCTION}

Origin of fairs could be related to an excess of production. Exchange was established from that exceeding first among groups without any kind of place to make this happen. A natural necessity of these fairs that could join all available products changing excess for lack of other products was important. Therefore free fairs are an important mean to supply food for families since ancient times. It is important to know and to support this kind of commercialization structure. This knowledge can provide food security and life quality of population ${ }^{[1]}$.

Free fairs are economic and social phenomena very ancient and were known for Greeks and Romans. Romans had rules for creation and management of these fairs and these rules were established from the estate. Objective of these fairs become really important from commercial revolution. From XI century their number was increased until XIII century [2].

Dolzani and Jesus [3] describe fairs like a microcosm in social and economic and cultural landscape of some cities. Fairs are not only for buying and selling but for meeting and enjoying. It is a social fact with particular characteristics. In these fairs people change information, political articulation or just have fun.

However these fairs have problems with lack of hygiene, bad structure of stalls, commercialization of not allowed products, lack of safety and disorganization. Survival of these fairs are in risk because such problems. These problems are against sanitation laws, compromising quality of products and health of consumers [4].

According to article 10, volume 11, October 2001 from Social Security another important point would be machine operation in these environments that are related to severe and incapacitating work accidents. These problems have impacts on health and welfare of workers and social security. Most of these accidents could be avoided if these problems were taken place [5].

Number of work accidents achieve 720,1 thousands according Statistical Yearbook of Social Security in 2010 and represents a decrease of 4,3\% related to 2009. Medical assistance, temporary incapacity, permanent incapacity and decease reduced respectively 5,8\%, 4,1\%, 3,5\% and 5,9\%. Main consequences of work accidents were temporary incapacity with less than 15 days reached $42,5 \%$ and with more than 15 days were $41,6 \%$ [ 6 .

Risk maps are made to show risk points by graphics of distribution of them in several places of fair using circles in different colors and sizes [7].

So this work has an objective of knowing environmental risks in most visited repeatedly free fairs in Palmas. This work will establish control measures for maintenance of health and security of workers and consumers.

\section{MATERIAL AND METHODS}

\section{Quantitative and qualitative analysis}

First of all, Municipal Agriculture Secretary and Municipal Sanitation Surveillance of Palmas had a meeting with students to know which free fairs would be an object of this study. Regulatory agencies of fairs suggested two places for this study. One of them was in south region and another on region north of capital of Tocantins. First one was south region and then north region.

Qualitative evaluations were made in loco for knowing work process and identifying environmental risks. One of utilized methods was security work inspection. This inspection was made using an application adapted by Montelo et al. ${ }^{[4]}$ for free fairs. Main features considered on this security conditions diagnosis (or risks) in work place were specified on Regulatory Patterns. 
Quantitative studies were made using level of noisy measure, temperature and lightness. Level of noisy was taken using a digital model of decibel meter MSL-1350. This equipment uses compensation curve " $\mathrm{A}$ " and slow response. It was measured 30 strategic points for level of noisy in each fair. This was made for expressing better accuracy of work reality.

Temperature was measured with a digital infrared thermometer trade Text model 805. It was 33 points in both fairs. Lightness was utilized a digital light meter trade Minipa model MLM 1010. In this case 30 points were measured in both fairs.

\section{Elaboration of risk map}

After qualitative and quantitative evaluations it was verified main failures and a map of risk was made using Autocad 2012 software and then graphics of risk identification was plotted.

\section{RESULTS AND DISCUSSION}

It was observed that fairs do not have gas store and installations so they use gas recipients in both fairs. This is a severe risk to fair workers and consumers including explosions.

Santos [4] mentions importance of a good program for prevention fire in places with problems on electric systems, application of inadequate process for escape from gas, inappropriate installations and store of gas, lack of care by using fried equipments and connection of several equipments in one plug.

After analysis of risk maps of two fairs in north region fair a high level of ergonomic risk (Figure 1) was observed. Fair in south region presented a high level of physical risks in agricultural and workmanship areas. Similar results were observed for Montelo et al. [4].

Figure 1. Risk map fair the region North

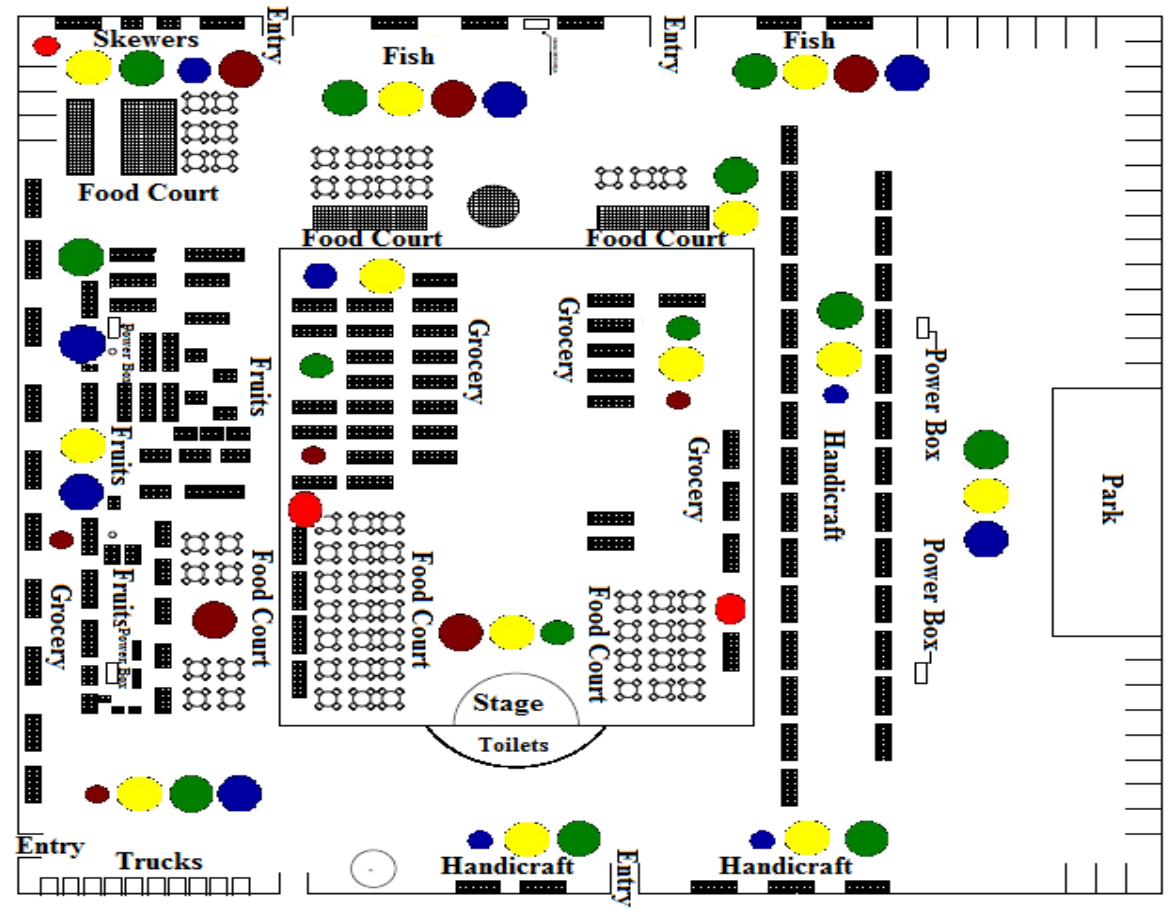


Figure 2. Risk map fair the region South

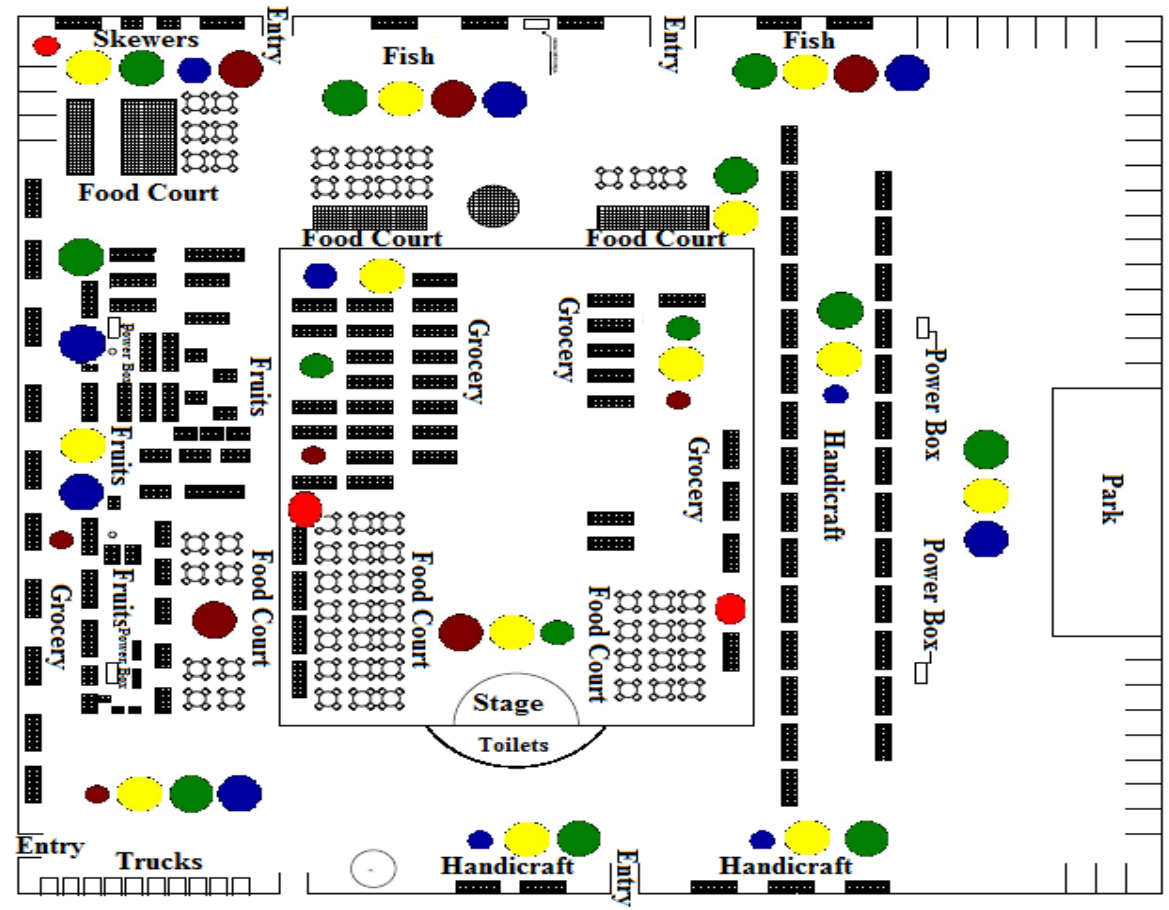

There are no extinguishers of fire in several points for both fairs that is recommended to Garcia and Cremonesi [8]. They point out importance of a good prevention of fire program in places where electric systems are deficient. In both risk maps (Figures 1 and 2) it can be viewed electricity cables on the ground, distribution box of electricity with no protection near agricultural, fishing, workmanship and food places. These areas are identified in green color. Similar results were observed by Monteloet al. [4]. Authors observed that for food places risks are in elements of work process.

For electric installations it is recommended a distribution box with circuit breakers for each branch. They are dimensioned according to demand. Wires and cables must be protected by electro ducts maintained suspended or underground on intense circulation paths of fair [?].

In fairs with provisory installations and totally removable like workers outside of both fairs it is necessary an electrician available to do mounting and dismounting of electrical net.
According to RDC n. 216 resolution of National Agency of Surveillance Sanitation lightning of preparation area must provide a good way for activities with no compromising hygiene and sensorial characteristics of food [?].

Toilets in both fairs are in bad conservation. There are no garbage collectors so they stay on the ground which is a biological risk for workers and consumers (Figures 1 and 2).

Containers must be near circulation areas of vehicles and in free access places to facilitate collecting. Collector vehicles must be closed with no hands contact according to RDC n.216 resolution, September 2004. This resolution displays about good practices of food services [10].

For garbage collecting Health Ministry [9] suggests put individual collectors near access ways that will be collected for municipal collecting service avoiding stink and possible contaminations. 
For noisy level almost work areas of south region fair (Table 1) exceed established parameters of Regulatory Pattern 15 about 8 hours of work that has a maximum value of 85 decibels $(\mathrm{dB})$ for insalubrity [9]. Except for coffee grinder that achieve $85 \mathrm{~dB}$ like described previously and clothes and workmanship areas that presented maximum value of $81,3 \mathrm{~dB}$. These high levels can result in tiredness, anger, headaches, decrease of hearing, increase of blood pressure, problems of digestive system, tachycardia and risk of heart attack.

Table 1. Noise level evaluation

\begin{tabular}{l|c|c}
\hline \multicolumn{1}{c}{ Areas } & \multicolumn{2}{c}{ Noisy Level (dB) } \\
\cline { 2 - 3 } & North region & South region \\
\hline Vegetables and fruits & $63.2-76.4$ & $75.5-89$ \\
Coffee grinder & - & 85 \\
Sound near stage & $63.8-80.3$ & $87.9-94$ \\
External area & - & - \\
Fishery & $74.3-74.7$ & $75.6-85.6$ \\
Cheese & - & $78.1-90.1$ \\
Food Place & $74.4-78.5$ & $87.6-94.2$ \\
Clothes and workmanship commercialization area & $66.4-74.4$ & $77.3-81.3$ \\
\hline
\end{tabular}

For north region fair it was observed that in all work areas noisy level (Table 1) was according to Regulatory Pattern as mentioned before ${ }^{[?]}$.

Temperature level on south region fair (Table 2) was measured and then it was observed an irregular packing of food in inappropriate temperature that can cause health problems to consumers. Mayonnaise is a typical example that high temperatures $(22.4-23.3)$ are good for growth of microorganisms that are responsible for a lot of pathologies [11,12].

Table 2. Temperature evaluation

\begin{tabular}{l|cc}
\hline \multicolumn{1}{c}{ Areas } & \multicolumn{2}{c}{ Temperature Level ( $\left.{ }^{\circ} \mathbf{C}\right)$} \\
\cline { 2 - 3 } & North region & South region \\
\hline Vegetables and fruits & $26.8-29.8$ & $21.1-23.4$ \\
Fishery (band saw) & $14.4-18.1$ & $-0.6-12.8$ \\
Cheeses & - & $15.9-22.4$ \\
Food Place (Mayonnaise) & $26.1-33.4$ & $22.4-23.3$ \\
Meals ready-to-eat (soups) & $41.2-51.2$ & - \\
Metal sheet for frying & 120.8 & - \\
\hline
\end{tabular}

In north region fair temperature level (Table 2) shows also an irregular storage of certain food. This can cause health problems in consumers of these products. Fishes are an example that with high temperatures $(14.4-18.1)$ they can favor growth of microorganisms that causes several pathologies [13]. Comparing temperature of fishes in both fairs it can be noticed that in south region fair this storage is a little better than in north region fair but has failure in storage yet.

Montelo et al. ${ }^{[4]}$ and Germano \& Germano [14] point out that food in free fairs and public markets can be vehicles of contamination by microorganisms causing infections. In these places microorganisms are a potential biological risk for consumers mainly when 
foods are exposed in raw form, like they are in these places and in big quantities.

Lightning level found in south region fair (Table 3) shows that the most deficient area is fish commercialization. This are presented a $20-42$ lux and this is a unsecure condition according RDC no 216 [10].

Table 3. Qualitative evaluation of lightning

\begin{tabular}{l|c|c}
\hline \multicolumn{1}{c}{ Areas } & \multicolumn{2}{c}{ Lightninglevel (lux) - Night } \\
\cline { 2 - 3 } & North region & South region \\
\hline Vegetables and fruits & $21-90$ & $15-90$ \\
External area & - & - \\
Fishery & $21-28$ & $20-33$ \\
Band saw & $21-28$ & $22-42$ \\
Fruits commercialization & $21-90$ & $24-35$ \\
Food Place & $22-28$ & $21-77$ \\
Meals ready-to-eat (soups) & $28-32$ & $19-51$ \\
Workmanship & - & $19-48$ \\
\hline
\end{tabular}

In north region fair level of lightning is on Table 3. Lightning level is deficient on fish commercialization too that presented 21 lux. As in south region fair this is an insecure condition. Lack of lightning or less of that can cause visual problems, tiredness and work accidents.

This situation can be worse because of band saw operators in both fairs that do not use gloves of steel mesh, EPI indicated for this activity according to Regulatory Pattern n. 6 of Work Ministry (Brazil, 2007). These gloves are necessary because equipment offer accident risk with partial or total amputation of members. Similar observations were carried out for Monteloet al. [4].

\section{CONCLUSION}

Obtained results shows us that fair workers have problems with high temperatures, bad quality of electrical installations, physical and psychological tiredness, stress by high level of noisy, pain in legs and backs by standing long time. This is a risk for physical and psychological security of workers.

After analysis it was observed it is necessary government investments in training of professionals and improvement on physical structure of fairs. Layout changes, modern installations, use of new technologies to minimize or eliminate damages and critical points of control in fairs, since reduction of accidents and incidents in these work places as prevention of food poisoning of those which eat meals prepared in these kitchens.

\section{REFERENCES}

[1] Oliveira AT et al. Condições de higiene das feiras livres dos municípios de Bananeiras, Solânea e Guarabira. In: X Encontro de Extensão da Universidade Federal da Paraíba; 2007; João Pessoa; BR. João Pessoa: Centro de Formação de Tecnólogos. Departamento de Tecnologia Rural/PROBEX, UFPB; 2007.

[2] Enciclopédia Luso-Brasileira. 1995. v. 8, p. 502.

[3] Dolzani M, Jesus GM. O direito à cidade: cem anos de feira livre na cidade do Rio de Janeiro [internet]. Rio de Janeiro, 2012 [acesso em 12 maio 2012]. Disponível em: http://www.uerj.br

[4] Montelo RO, Martins, GASM, Teixeira, SMF. Avaliação das condições de segurança e higiene do trabalho: estudo de caso na feira livre do agricultor em Palmas - Tocantins. UNOPAR Cient Ciênc Biol Saúde. 2011;13(4):263-70.

[5] Pinheiro, VC. Segurança do trabalho no Brasil [internet]. 2001 [acesso em 24 maio 2012]. Disponível em http://www1.previdencia.gov.br/docs/pdf/inf_outubro01. pdf. 
[6] AEPS. Anuário Estatístico da Previdência Social 2010 [acesso em 05 jul 2012]. Disponível em http://www.mpas.gov.br/arquivos/office/3_111202105619-646.pdf.

[7] Ponzetto G. Mapa de Riscos Ambientais NR-5. $2^{a}$ Ed. São Paulo: Editora LTR; 2007.

[8] Garcia JMR, Cremonesi KCP. Programas prevencionistas: subsídios para análise de riscos. Goiânia: AB; 2006.

[9] Brasil. Manuais de Legislação Atlas. Segurança e Medicina do Trabalho. Lei $\mathrm{N}^{\circ}$ 6514, de 22 de dezembro de 1977. Normas Regulamentadoras - NR - 1 a 33, Portaria $\mathrm{N}^{\circ}$ 3.214, de 08 de junho de 1978. Legislação complementar. 63a ed. São Paulo: Editora Atlas; 2007.

[10] Brasil. Agência Nacional de Vigilância Sanitária. Resolução RDC no 216, de 15 de setembro de 2004 [internet]. [acesso em 23 maio 2012]. Disponível em http://portal.anvisa.gov.br/wps/wcm/connect/aa0bc3004 74575dd83f2d73fbc4c6735/rdc_n_216_de_15_de_setembr o_de_2004.pdf.
[11] Silva EV, Neto, JFS, Melo, FSN, Araújo, AS. Análise da qualidade microbiológica de maioneses comercializadas em Pombal. Caderno verde de agroecologia e desenvolvimento sustentável. 2011;1(1).

[12] Guerra CB, Miguel DP. Staphylococcus coagulase positiva e coliformes fecais em pratos frios adicionados de molho de maionese. Cadernos de Pós-Graduação da FAZU. 2011;2.

[13] Campos DS, Paiva ZC. Condições higiênico-sanitárias do pescado comercializado em feira no município de Manaus - AM. Cadernos de Pós-Graduação da FAZU. 2011;2.

[14] Germano PML, Germano MIS. Higiene e vigilância sanitária de alimentos. São Paulo: Varela; 2001. 